\title{
Comparative changes in density and demography of large herbivores in the Masai Mara Reserve and its surrounding human-dominated pastoral ranches in Kenya
}

\author{
Nina Bhola $\cdot$ Joseph O. Ogutu $\cdot$ Hans-Peter Piepho $\cdot$ Mohamed Y. Said • \\ Robin S. Reid $\cdot$ N. Thompson Hobbs $\cdot$ Han Olff
}

Received: 27 June 2011/Accepted: 17 February 2012/Published online: 4 March 2012

(C) The Author(s) 2012. This article is published with open access at Springerlink.com

\begin{abstract}
Wildlife habitats in pastoral lands adjoining protected areas in east African savannas are getting progressively degraded, fragmented and compressed by expanding human populations and intensification of land use. To understand the consequences of these influences on wildlife populations, we contrasted the density and demography of 13 wild and three domestic large herbivores between the Masai Mara National Reserve and the adjoining pastoral ranches using aerial surveys conducted in the wet and dry seasons during 1977-2010. Species of different body sizes and feeding styles had different densities between landscapes and seasons. Small-sized herbivores, requiring short, nutritious grasses, and browsers were more abundant in the ranches than the reserve in both seasons.
\end{abstract}

Electronic supplementary material The online version of this article (doi:10.1007/s10531-012-0261-y) contains supplementary material, which is available to authorized users.

N. Bhola $(\bowtie) \cdot$ H. Olff

Community and Conservation Ecology Group, Centre for Ecological and Evolutionary Studies, University of Groningen, PO Box 11103, 9700 CC Groningen, The Netherlands e-mail: nina.bhola@gmail.com

J. O. Ogutu · H.-P. Piepho

Institute of Crop Science, Bioinformatics Unit, University of Hohenheim, 70599 Stuttgart, Germany e-mail: jogutu2007@gmail.com

H.-P. Piepho

e-mail: piepho@uni-hohenheim.de

M. Y. Said

International Livestock Research Institute, PO Box 30709, Nairobi 00100, Kenya e-mail: M.Said@cgiar.org

R. S. Reid

Center for Collaborative Conservation, Colorado State University, Fort Collins, CO 80523, USA

e-mail: Robin.Reid@colostate.edu

N. T. Hobbs

Natural Resource Ecology Laboratory and Graduate Degree Program in Ecology,

Colorado State University, Fort Collins, CO 80524, USA 
Medium-sized herbivores moved seasonally between landscapes. Larger-bodied herbivores, requiring bulk forage but less susceptible to predation, were more abundant in the reserve than the ranches. The proportions of newborn warthog (Phacochoerus africanus) and juvenile topi (Damaliscus korrigum) were higher in the ranches, with shorter grasses and lower predation risk than in the reserve. These results suggest that pastoral lands adjoining protected areas in African savannas are important as seasonal dispersal and breeding grounds for wild herbivores. However, human population growth and dramatic land use changes are progressively degrading wildlife habitats in pastoral areas, thus restricting the seasonal wildlife dispersal movements between the protected areas and adjoining pastoral lands. Conservation efforts should focus on (1) creating and maintaining functional heterogeneity in protected areas that mimic moderate pastoral grazing conditions to attract small and medium-bodied grazers and (2) securing dispersal areas, including corridors, to ensure continued seasonal large herbivore movements between protected and pastoral systems.

Keywords Large herbivores · Pastoralism · Protection · Distribution · Seasonal movements

\section{Introduction}

Pastoralism is the economic mainstay of most inhabitants of grasslands of East Africa, who also often derive limited income from wildlife-based tourism. However, rapid human population growth, expansion of settlements (Lamprey and Reid 2004), cultivation (Serneels et al. 2001; Thompson and Homewood 2002) and transition from semi-nomadic pastoralism to a sedentary lifestyle (Western et al. 2009), are progressively altering the vegetation composition and structure of these savanna grasslands. Concurrent with these processes, a transition from communal land tenure to private land ownership in the pastoral ranches, habitat fragmentation through land privatization and subsequent subdivision (Galvin et al. 2008; Homewood et al. 2009), rising temperatures and recurrent severe droughts (Ogutu et al. 2007) threaten the future survival of large mammalian populations in some savanna ecosystems, such as the Mara-Serengeti of Kenya and Tanzania (Ottichilo et al. 2001; Ogutu et al. 2009).

Settlements are expanding faster nearer than farther away from protected areas in Latin America and Africa due to enhanced economic activities and opportunities inside and around protected-area boundaries (Wittemyer et al. 2008). A spectacular example of this expansion is found on pastoral ranches surrounding the Masai Mara National Reserve (MMNR) in Kenya (Norton-Griffiths et al. 2008). The progressive intensification of land use, sedentarization and diversification of livelihoods are associated with rapidly declining wildlife numbers in the last three decades in pastoral systems of east Africa, including the Mara (Broten and Said 1995; Ottichilo et al. 2000; Ogutu et al. 2009), Laikipia (Georgiadis et al. 2007) and Athi-Kaputiei (Reid et al. 2008) regions of Kenya and the Tanzanian Tarangire-Simanjiro Plains (Msoffe et al. 2011). The declines are related to increasing numbers of settlements, people, poaching and major land use changes on the pastoral ranches (Serneels and Lambin 2001; Georgiadis et al. 2007; Reid et al. 2008; Ogutu et al. 2009). The patterns of declining wildlife in protected areas of East Africa (Stoner et al. 2007; Western et al. 2009) are consistent with early forecasts of major reductions, and even extinctions of many wildlife populations expected in East African reserves as a 
consequence of increasing insularization (Newmark 1996) and displacement of wildlife by increasing livestock incursions into protected areas (Butt et al. 2009).

These changes progressively impede traditional seasonal wildlife movements between protected areas and their adjoining pastoral systems. Several studies have demonstrated seasonal movements by ungulates between protected areas and adjoining pastoral ranches in Amboseli (Western 1975; Mworia et al. 2008), Mara (Stelfox et al. 1986) and AthiKaputiei Plains (Reid et al. 2008), thus supporting the prediction that the processes associated with land use change will continue to erode grazing areas so that livestock will compete increasingly with wildlife for resources, resulting in wildlife and livestock population declines (Homewood et al. 2009).

By moving seasonally between protected and pastoral areas, ungulates maximize their resource requirements while minimizing predation risk (Hopcraft et al. 2010). However, these seasonal dispersal movements might be constrained by body size (Hopcraft et al. 2011) through its influence on food quantity and quality requirements as well as vulnerability to predation.

More specifically, large herbivores can tolerate more fibrous and lower-quality diets than can small herbivores because of their larger gastrointestinal tracts and lower specific metabolic requirements (Demment and Van Soest 1985; Owen-Smith 1988). Furthermore, a smaller fraction of large herbivores die from predation than do small herbivores because large herbivores are more difficult for predators to capture (Sinclair et al. 2003). Thus, body size can be expected to control responses of herbivore abundance to seasonal disparities in forage quantity and quality and predation risk between protected and pastoral landscapes.

The MMNR in Kenya supports a high abundance and diversity of resident wildlife and offers a dry season habitat for migratory ungulates from the Serengeti National Park in Tanzania to the south and the neighbouring Loita Plains to the northeast (Stelfox et al. 1986; Ottichilo et al. 2001; Thirgood et al. 2004). Extensive grasslands in the pastoral areas adjacent to the MMNR also provide wet season dispersal ranges for resident wildlife (Stelfox et al. 1986). Yet, despite the significance of pastoral areas to wildlife, few studies have evaluated the relative impact of pastoralism versus protection on wildlife population density and demography in African savannas (Caro 1999a; Rannestad et al. 2006; Wallgren et al. 2009). Even fewer studies have investigated the impacts of pastoralism and protection on long-term comparative changes in density (Caro 1999b; Reid et al. 2008).

Here, we analyze the influence of protection in the MMNR and pastoralism in the adjoining Koyiaki pastoral ranch (see below) on comparative changes in the density of 13 wild herbivores. We consider the following wild herbivores, in order of increasing body size, Thomson's gazelle (Gazella thomsoni), impala (Aepyceros melampus), warthog, Grant's gazelle (Gazella granti), topi, wildebeest (Connochaetes taurinus), Coke's hartebeest (Alcelaphus buselaphus cokeii), defassa waterbuck (Kobus ellipsiprymnus), zebra (Equus burchelli), eland (Taurotragus oryx), buffalo (Syncerus caffer), giraffe (Giraffa camelopardalis), and elephant (Loxodonta africana) (Table 1). We also consider the densities of three domestic herbivore species, namely sheep (Ovis aries), goats (Capra hircus) and cattle (Bos indicus). We used data collected from systematic reconnaissance aerial surveys conducted during wet and dry seasons by the Kenya Department of Resource Surveys and Remote Sensing (DRSRS) from 1977 to 2010. We supplemented these comparisons with parallel comparisons based on ground mapping censuses conducted in the MMNR and Koyiaki in November 1999 and 2002 (Reid et al. 2003). We also compared age and sex composition counts of a subset of six of the 13 wild herbivores, namely, impala, warthog, topi, hartebeest, zebra and giraffe, conducted in 2003 and 2004 to establish the influence of protection and pastoralism on the demography of these herbivore 
Table 1 Functional groupings of species by body mass (Coe et al. 1976), feeding and foraging styles

\begin{tabular}{|c|c|c|c|c|}
\hline Common name & Scientific name & Mass $(\mathrm{kg})$ & Dietary guild & Residence guild \\
\hline Thomson's gazelle & Gazella thomsoni & 15 & Grazer & Migratory \\
\hline Sheep + goats & Ovis aries + Capra hircus & 16 & Mixed feeder ${ }^{b}$ & Resident \\
\hline Impala & Aepyceros melampus & 40 & Mixed feeder & Resident \\
\hline Warthog & Phacocoerus africanus & 45 & Grazer & Resident \\
\hline Grant's gazelle & Gazella granti & 50 & Mixed feeder & Resident \\
\hline Topi & Damaliscus korrigum & 100 & Grazer & Resident \\
\hline Wildebeest & Connochaetes taurinus & 120 & Grazer & Migratory \\
\hline Hartebeest & Alcelaphus buselaphus cokeii & 125 & Grazer & Resident \\
\hline Defassa waterbuck & Kobus ellipsiprymnus & 160 & Grazer & Resident \\
\hline Cattle & Bos indicus & 180 & Grazer & Resident \\
\hline Zebra & Equus burchelli & 200 & Grazer & Migratory \\
\hline Eland & Taurotragus oryx & 350 & Mixed feeder & Migratory \\
\hline Buffalo & Syncerus caffer & 700 & Grazer & Resident \\
\hline Giraffe & Giraffa camelopardalis & 1,250 & Browser & Resident \\
\hline Elephant & Loxodonta africana & 5,500 & Mixed feeder & Dispersal $^{\mathrm{a}}$ \\
\hline
\end{tabular}

\footnotetext{
${ }^{a}$ Wanders widely seasonally but do not engage in regular seasonal migrations

b Sheep are grazers, and goats are browsers
}

species. The six species were selected because reliable methods for ageing and sexing them had already been developed and tested as part of a 15-year monitoring program spanning 1989-2003 (Ogutu et al. 2008).

Our hypotheses were based on differences in grass heights and predator densities between the MMNR and the pastoral ranches quantified by Ogutu et al. (2005) and Reid et al. (2003). Grass height influences both forage quality and predation risk. In the wet season less heavily grazed grasses, such as occur in most parts of the Mara reserve, become tall and therefore allocate more energy to developing structural fibers with higher carbon to nitrogen ratios, thereby diluting the concentration of nitrogen and phosphorous available to herbivores (Anderson et al. 2007). From an herbivore's perspective, the digestibility of grasses is therefore inversely related to rainfall amount (Hopcraft et al. 2011). Mature grasses of tall stature are thus particularly unfavourable for small and medium herbivores due to their low digestibility and nutritional quality (Fritz and Duncan 1994; Olff et al. 2002). In contrast, short grasses maintained by heavy livestock grazing, such as those in the pastoral areas of the Mara in the wet season (Ogutu et al. 2005), have higher digestibility and nutritional quality. Heavy livestock grazing on the ranches, furthermore, tends to promote production of more net grass biomass, which in turn attracts more herbivores than in the reserve with no livestock. Consequently, sustained livestock grazing in the ranches, by keeping grass stem biomass low, renders grasses more digestible and enhances their nutritional quality (McNaughton 1976). This enables herbivores to realize greater protein consumption on the ranches than they do in the reserve in the wet season. As well, nutrientrich pastoral settlement (boma) sites in the ranches represent key sources of nutritionally sufficient forage, especially for lactating females in the wet season (Muchiru et al. 2008; Augustine et al. 2010).

In addition, during the wet season, it is likely that lions are more abundant in the reserve (Reid et al. 2003), with taller grass cover, than in the ranches (Ogutu et al. 2005). Predator 
densities are also higher in the reserve than in the ranches in the dry season (Reid et al. 2003), reflecting not only their preference for high grass cover, but also avoidance of human and livestock activities on the ranches (Ogutu et al. 2005). Since predation risk increases with grass height in the Serengeti (Hopcraft et al. 2005) and Mara Region (Kanga et al. 2011) and since grass cover is shorter and predator density is lower on the ranches than in the reserve, small and medium herbivores likely experience lower predation risk on the ranches than in the reserve (Sinclair et al. 2003).

In the dry season, when surface water and forage availability are reduced, heavy livestock grazing in the pastoral ranches forces wildlife to disperse to the reserve, where the migratory wildebeest and zebra and fires have removed the taller grasses and improved visibility. Thus, heavy livestock grazing in the pastoral ranches facilitates small and medium-sized herbivores in the wet season, but competition with livestock in the dry season for food and water, pushes them into the reserve where they are facilitated by migratory herds, which also absorb most of the predation pressure (Ogutu et al. 2008).

Accordingly, we formulated the following four initial expectations based on herbivore body size. (1) The densities of the small-sized herbivores $(15-50 \mathrm{~kg}$ ), would be higher in the Koyiaki pastoral ranch in both seasons due to the higher prevalence of short grass that is safer year round. (2) The densities of medium-sized grazers (100-200 kg) would be higher in the Koyiaki ranch in the wet season when grass is short (and safe) and green (and nutritious), but would be higher in the reserve with higher quantities of grass in the dry season when grass dries out and becomes too short on the Koyiaki ranch. (3) The density of large wild herbivores $(>350 \mathrm{~kg}$ ) would be higher year-round in the reserve than in Koyiaki ranch if they perceive lower predation risk (Sinclair et al. 2003) and satisfy their energy demands by ingesting large quantities of low-quality forage (Demment and Van Soest 1985). Finally, (4) the lower number of predators and presumably lower predation risk on Koyiaki ranch, due to the shorter grasses of higher nutritional quality, and better predator visibility, would lead to a higher proportion of the pregnant females bearing and raising their young on the ranches than in the reserve.

Since the changes in wildlife distribution between the reserve and the ranches constitute essentially an unreplicated natural experiment, we used the protected Mara reserve as an ecological baseline area or benchmark that is relatively free of human impact to understand the consequences of impacts of livestock and human use of the human-dominated pastoral lands on seasonal and long-term patterns of wildlife distributions in the Mara Region (Sinclair 1998; Sinclair et al. 2002). We conduct replicate comparisons of herbivore densities between the reserve and the ranches based on 50 independent aerial surveys spanning 41 years conducted using the same technique to increase our confidence in, and ability to, separate the impacts of livestock and human use of the pastoral ranches on wildlife distributions despite the lack of true replication, which is difficult to achieve experimentally at landscape scales.

\section{Study area}

The Mara Reserve is located in southwestern Kenya and borders the Serengeti National Park in Tanzania to the south. It covers some $1,530 \mathrm{~km}^{2}$ and is bounded by the Siria escarpment on the west, Koyiaki $\left(931 \mathrm{~km}^{2}\right)$ and Olkinyei $\left(804 \mathrm{~km}^{2}\right)$ pastoral ranches on the north and Siana pastoral ranch $\left(1,315 \mathrm{~km}^{2}\right)$ on the east (Ogutu et al. 2005) (Fig. 1). The reserve and the surrounding pastoral areas support annual migrations of enormous herds of wildebeest and zebra and small herds of eland from the Tanzanian Serengeti and much smaller herds of wildebeest, zebra and Thomson's gazelles from the Kenyan Loita Plains, 


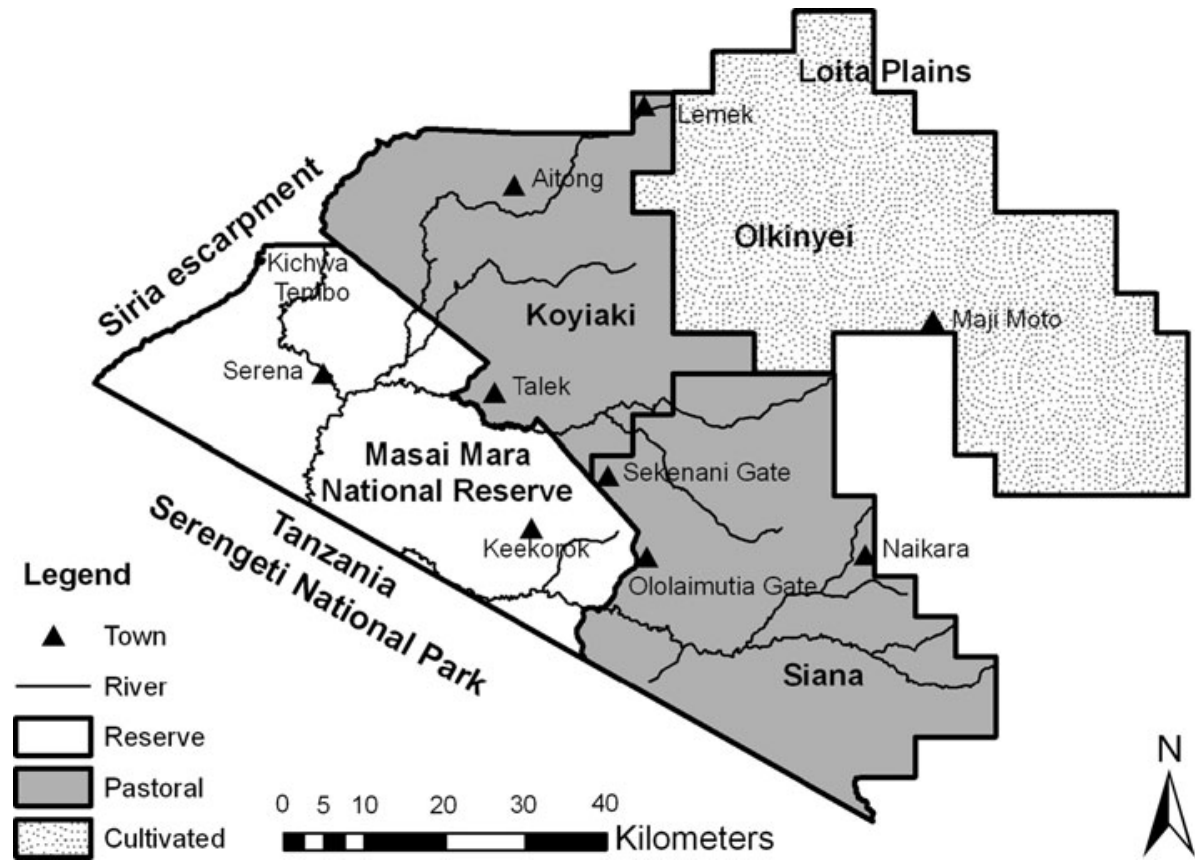

Fig. 1 Map of the Mara Region of Kenya showing the Masai Mara National Reserve and its adjoining pastoral ranches, grouped into pastoral and cultivated areas (large-scale, commercial cultivation)

to the northeast of the reserve (Maddock 1979; Stelfox et al. 1986). Traditional pastoralism, cultivation, and wildlife tourism constitute the major forms of land use in the pastoral ranches (Homewood et al. 2001). The major livestock species kept in the ranches include cattle, sheep, goats and donkeys (Lamprey and Reid 2004). The reserve is a nationally protected area in which wildlife conservation and tourism are the only permitted land uses but illegal livestock grazing is common, especially in dry years (Reid et al. 2003; Butt et al. 2009). There is no physical barrier to wildlife movements between the reserve and the surrounding pastoral areas. Hereafter, we refer to the reserve and all its surrounding pastoral ranches as the "Mara Region".

The vegetation consists predominantly of open grass plains dominated by Hyparrhenia filipendula and Themeda triandra, interspersed with Acacia gerrardii and Terminalia trees, shrublands and riverine forests (Epp and Agatsiva 1980). Numerous seasonal streams drain the area, but only the Mara River and sections of the Sand and Talek Rivers typically contain water year-round. The Mara River originates in the Mau escarpment to the north of the Mara region. Annual rainfall during 1989-2003 averaged 1,010 mm and increased from $877 \mathrm{~mm}$ at Ololaimutia Gate in the southeast to $1,341 \mathrm{~mm}$ at Kichwa Tembo in the northwest of the MMNR (Ogutu et al. 2011). Rainfall is bimodal in the Mara Region, with the wet season spanning late November of the previous year to June of the current year and the dry season covering July-early November of the current year. The short rains fall during late November-December and the long rains during March-June. Rainfall increases spatially from $500 \mathrm{~mm}$ per year in the Serengeti Plains in the southeast to over 1,200 $\mathrm{mm}$ in the northwest of the Mara Region (Pennycuick and Norton-Griffiths 1976). 


\section{Methods}

The Kenya Department of Resource Surveys and Remote Sensing (DRSRS) conducted 50 aerial surveys in the Mara Region from 1977 to 2010, covering the entire Mara Region $\left(6,400 \mathrm{~km}^{2}\right)$, including the reserve $\left(1,530 \mathrm{~km}^{2}\right)$, and the surrounding pastoral ranches $\left(4,870 \mathrm{~km}^{2}\right)$. Surveys were undertaken either in the wet (Jan-June or Nov-Dec) or dry (Jul-Oct) season month(s) of each year except 1981, 1988, 1995, 1998, 1999, 2001, 2003, 2004 and 2006 when surveys were not conducted due to financial constraints (Stelfox et al. 1986; Broten and Said 1995; Ottichilo et al. 2000, 2001; Ogutu et al. 2011). The surveys followed systematic strip transects located $5 \mathrm{~km}$ apart and segmented into sampling grid cells of $5 \times 5 \mathrm{~km}^{2}$ (Norton-Griffiths 1978). The transects were oriented in an east-west or north-south direction and were flown at a fixed height of about $90 \mathrm{~m}$ above the ground during 1977-1985 and about $120 \mathrm{~m}$ thereafter (Ottichilo et al. 2000). The number of animals observed within a calibrated survey strip defined by two parallel rods on the wing struts of the aircraft and running through the centre of the $5 \times 5 \mathrm{~km}^{2}$ grid cell was recorded. The survey strip spanned an average width of $263 \mathrm{~m}$ on the ground, corresponding to an average sampling intensity or fraction of $4.8 \%$ of the $5 \times 5 \mathrm{~km}^{2}$ grid cell area (Ogutu et al. 2011). The expected number of animals per $25 \mathrm{~km}^{2}$ grid cell area was thus estimated as the actual number counted in each $25 \mathrm{~km}^{2}$ grid cell times 100 divided by the sampling fraction. The mean count for each species per survey in the reserve was expressed as the average of the estimated population size over all the $25 \mathrm{~km}^{2}$ grid cells in the reserve ( $n=61$ cells, covering a total area of $1,525 \mathrm{~km}^{2}$ ). The same applies to the Koyiaki pastoral ranch $\left(n=37\right.$, for a total area of $\left.925 \mathrm{~km}^{2}\right)$. Ottichilo (1999) and Ottichilo and Khaemba (2001) have demonstrated the reliability of the estimates of wildlife and livestock population sizes from the DRSRS count method. From the 50 surveys, we selected counts of 13 wild herbivore species, comprising four small-sized herbivores: Thomson's gazelle, Grant's gazelle, impala and warthog, five medium-sized herbivores: topi, hartebeest, wildebeest and zebra, four large herbivores: eland, buffalo, giraffe and elephant; and three species of livestock, namely sheep and goats (which are lumped together during surveys as 'sheep and goats' because they occur in mixed herds that are hard to distinguish reliably from the air) and cattle to represent a range of functional groups based on body size, feeding and foraging styles (Table 1). Of the 50 surveys 33 were conducted in the wet season and 17 in the dry season. Averaging population density estimates for each species in each grid cell over all surveys conducted in each season in 1 year produced 20 surveys for the wet season (late November-June) and 12 for the dry season (July-early November), which we used for analysis.

\section{Ground mapping census of wildlife and livestock}

Two ground mapping censuses of wildlife and livestock in the MMNR and the adjacent pastoral ranches were conducted in early November 1999 and 2002 when dry conditions prevailed and the grass was still short, due to heavy grazing by migratory wildlife (Reid et al. 2003). The first census covered an area of $1,544.2 \mathrm{~km}^{2}$, including sections of Koyiaki and Lemek pastoral ranches, and the MMNR. This census was carried out by 12 teams totaling 40 people using 12 vehicles in both the reserve and the ranches. The second census covered 2,212 $\mathrm{km}^{2}$ and included Koyiaki, Lemek, Siana and a small part of southwestern Olkinyei ranches. This census was carried out by 22 teams totaling 84 people. The census area was partitioned into contiguous $0.33 \times 0.33 \mathrm{~km}^{2}$ sub-blocks to obtain fine resolution counts. The teams counted 7,606 sub-blocks in the reserve and 6,295 sub-blocks in the 
ranches in 1,999 and 11,117 sub-blocks in the reserve and 8,794 sub-blocks in the ranches in 2002 (Reid et al. 2003; Ogutu et al. 2010). The sampling teams navigated vehicles down the centers of each $1 \times 1 \mathrm{~km}^{2}$ block and allocated all animals observed into one of the nine nearest $0.33 \times 0.33 \mathrm{~km}^{2}$ sub-blocks using a global positioning system (GPS). The counts per $0.33 \times 0.33 \mathrm{~km}^{2}$ sub-blocks were converted to densities per $\mathrm{km}^{2}$ by multiplying them by nine. The mean density and corresponding standard errors were calculated as the average density over all sub-blocks in the reserve and ranches. The mean count for each species in the reserve was expressed as the average of the estimated population size over all the per $0.33 \times 0.33 \mathrm{~km}^{2}$ sub-blocks in the reserve. The same applies to Koyiaki pastoral ranch. We used these censuses to validate distribution patterns derived from the aerial surveys during the dry season, including one aerial survey that was conducted at the same time as the ground mapping census in 2002.

Age and sex composition counts of wildlife

Ogutu et al. (2006), in collaboration with the World Wide Fund for Nature (WWF), carried out two further vehicle ground sample counts of impala, warthog, topi, hartebeest, zebra, and giraffe including their age and sex. These counts were conducted in the MMNR, Koyiaki and a small section of Siana ranch in November 2003 and April 2004. The November 2003 survey was also conducted during the dry season. In contrast, the April 2004 survey was conducted in the late-wet season. They used a strip-transect sampling technique assuming complete census of all animals within a fixed strip width of $100 \mathrm{~m}$ either side of the transect centerline (Ogutu et al. 2006). The transects were distributed over the MMNR and pastoral ranches in proportion to their areas, with 22 transects established in the reserve and 13 in Koyiaki. Each transect was $10 \mathrm{~km}$ long. After every $1 \mathrm{~km}$ along each transect, the vehicle was stopped and the numbers, age class relative to adult size, sex and GPS locations of wildlife were recorded within $200 \mathrm{~m}$ on either side of the transect centerline. These species were classified, whenever possible, into three age classes: newborns ( $<1$ month), juveniles (1-18 months), adults ( $>18$ months). A combination of horn shape and length and body size were used to assign the herbivores to sex and age categories, however, ages were not assigned to adults (Sinclair 1995; Ogutu et al. 2008). Only the number of individuals sighted per age class in each transect, summed over all transects in the reserve and the ranches, from this dataset were used in analyses.

Comparing wildlife and livestock densities between landscapes

To account for clustering, non-normality and non-homogenous variances of animal counts, and varying frequency of counts we used negative binomial regression model for overdispersed count data to compare the mean density for each herbivore species in each $5 \times 5 \mathrm{~km}^{2}$ grid cell between the MMNR and Koyiaki pastoral ranch using the aod package in R (Lesnoff and Lancelot 2010; R Development Core Team 2010). More specifically, we used the log link function and specified the variance function for the negative binomial model as $\varphi u(1+(u / k))$, where $u$ is the mean, $\varphi$ is the overdispersion parameter and $k$ is the 'aggregation parameter'. Differences in the expected herbivore counts between landscapes were tested for significance using the Wald Chi-squared test (Draper and Smith 1998). A similar analysis was performed to compare the mean densities from the ground mapping censuses per $1 \times 1 \mathrm{~km}^{2}$ grid cells between the MMNR and Koyiaki pastoral ranch (Reid et al. 2003). 
Comparing age ratios and female proportions between landscapes

Due to low sample sizes for certain cross-classification cells, we used a Chi-square test for independence in a $2 \times 2$ frequency table, corrected for continuity using the Yates' correction for small sample sizes, to compare the ratio of newborns to adult females to that of juveniles to adult females for impala, topi and giraffe and the ratios of newborns to adults of both sexes to that of juveniles to adults of both sexes for warthog and zebra between the two areas based on counts pooled over the 2003 and 2004 surveys. We similarly compared the female proportion $(F /(F+M)$, where $F=$ female counts and $M=$ male counts $)$ for impala, topi and giraffe computed by pooling all individuals of the same sex over all age classes and the 2003 and 2004 surveys, separately for each area.

\section{Results}

Comparative changes in herbivore density

The details of differences in wildlife densities between the reserve and the ranches were complex and varied with species and season, but some consistent overall patterns were nevertheless evident.

\section{Small sized herbivores}

Most small herbivores were consistently more abundant in the ranches than in the reserve in both seasons (Fig. 2a, e). Interestingly, warthog did not conform to this pattern and showed a preference for the reserve in the dry season but for the ranches in the wet season (Fig. 2d). Sheep and goats were more abundant in the ranches than in the reserve, and their numbers increased noticeably during 2000-2010 relative to earlier years (Fig. 2b; Tables S1, S2).

\section{Medium sized herbivores}

Most medium-sized herbivores moved seasonally between the reserve and the ranches (Fig. 3a, f). However, hartebeest and waterbuck had slightly higher densities in the reserve during both seasons, but more especially in the wet season (Fig. 3c, d; Tables S1, S2). Topi, wildebeest and zebra had slightly higher densities in the reserve in the dry season when the migrants are present but somewhat higher densities in the ranches in the wet season (Fig. 3a, b, f; Tables S1, S2). More specifically, the resident wildebeest had lower densities in the ranches than in the reserve in the dry season but higher densities in the ranches than in the reserve in the wet season (Fig. 3b). Cattle were more abundant in the ranches than in the reserve in the dry season but more occurred in the reserve in the dry than in the wet season, and more recently (2000-2010) than in earlier years 1970-1999 (Fig. 3e; Tables S1, S2).

\section{Large sized herbivores}

Buffalo and elephant were consistently more abundant in the reserve than in the ranches in both seasons (Fig. 4b, d; Tables S1, S2). Eland had higher densities in the ranches than in the reserve in the wet season but lower densities in the ranches than in the reserve in the dry season (Fig. 4a). Giraffe did not show significant differences between the reserve and the ranches during the dry season, but were somewhat more abundant in the reserve. 
a
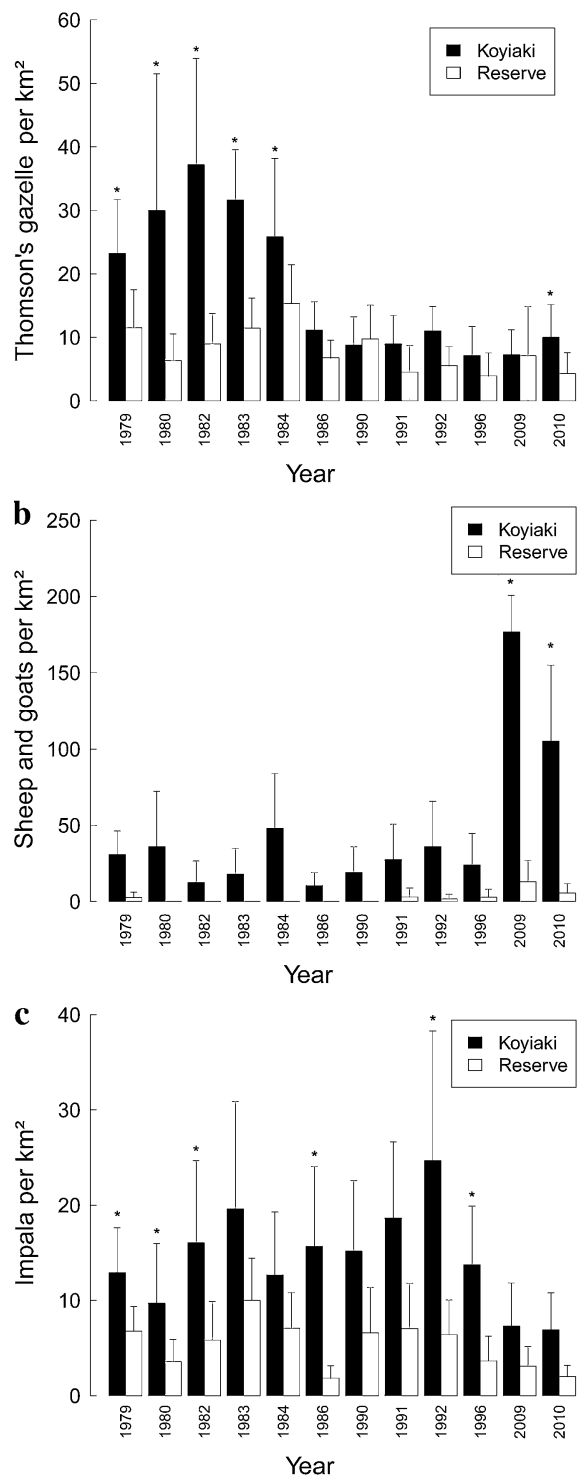

Wet season

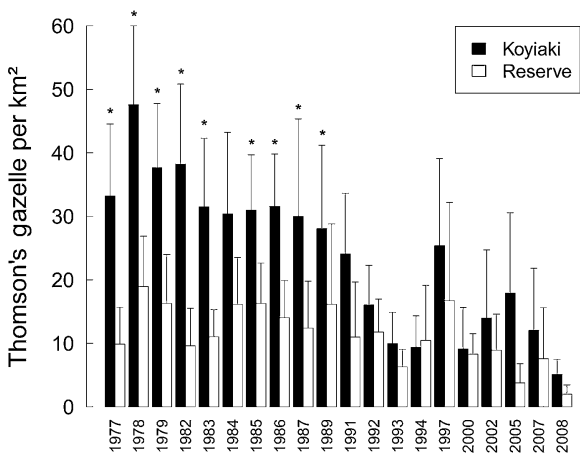

Year

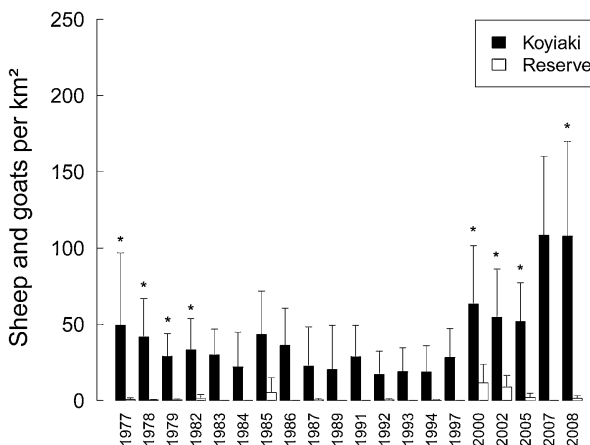

Year

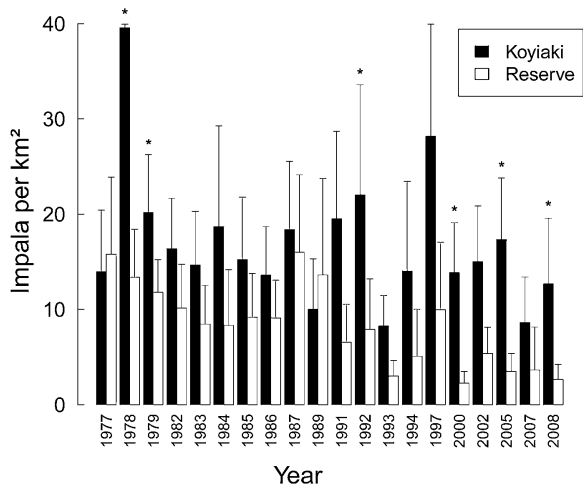

Fig. 2 Comparative changes in densities (number $/ \mathrm{km}^{2}$ ) of small pure grazers and mixed gazer/browsers, a Thomson's gazelle, b sheep and goats, $\mathbf{c}$ impala, $\mathbf{d}$ warthog and, e Grant's gazelle between the Mara Reserve (light bars) and the adjoining Koyiaki pastoral ranch (dark bars) during the dry and wet seasons based on the DRSRS aerial surveys from 1977 to 2010. Vertical lines show the 95\% pointwise confidence limits whereas stars indicate that the mean densities differed significantly between the reserve and Koyiaki

However, they were consistently more abundant in the ranches than the reserve in the wet season (Fig. 4c; Tables S1, S2).

The ground counts conducted in 1999 and 2002 confirmed that both gazelles, impala and giraffe were indeed more abundant in the ranches and that topi, hartebeest, wildebeest, zebra, eland, buffalo and elephant were more abundant in the reserve than in the ranches in 

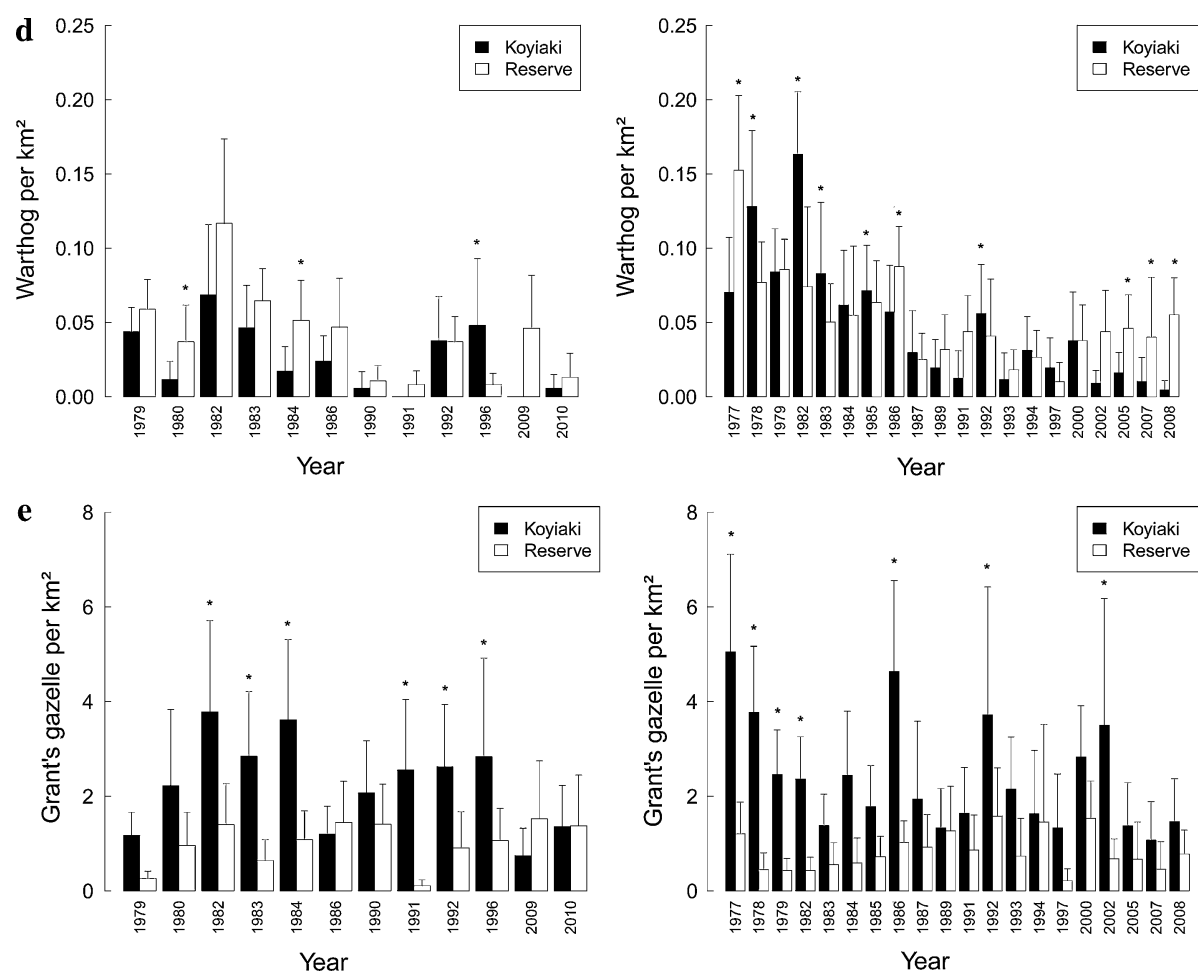

Fig. 2 continued

the dry season, as revealed by the aerial survey data. High variance in herd sizes rendered the apparently large differences in wildebeest densities between landscapes statistically insignificant. The ground counts also confirmed the greater abundance of livestock in the ranches than in the reserve shown by the aerial survey data (Table 2).

Comparisons of age ratios and female proportions between the reserve and the ranches

The population age composition of species differed between areas for warthog, topi and zebra. There were greater proportions of newborn warthog and juvenile topi in the ranches than in the reserve, but greater proportions of newborn topi and zebra in the reserve than in the ranches (Table 3). For hartebeest and waterbuck, numbers were too small for similar statistical tests. Only impala, topi, hartebeest and giraffe had sufficient sample sizes to statistically test differences in female proportions between the two areas. Among these species, female proportion was similar between landscapes for hartebeest and giraffe but was higher in the reserve than in the ranches among impala and topi (Table 4).

\section{Discussion}

Comparative changes in herbivore density

Although the differences in herbivore densities between the pastoral ranches and the reserve in any 1 year may also be influenced by inherent differences between the 
$\mathbf{a}$

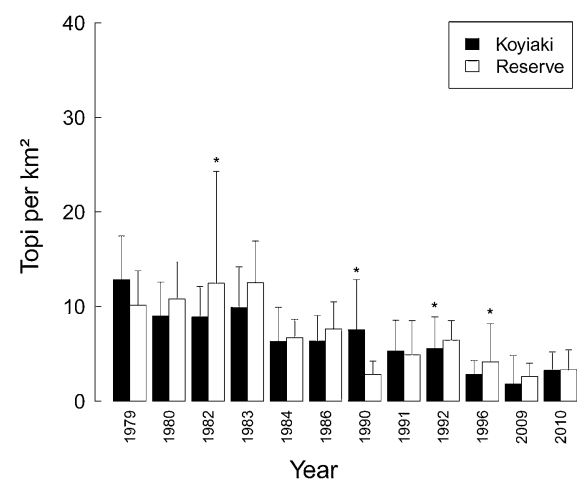

Wet season
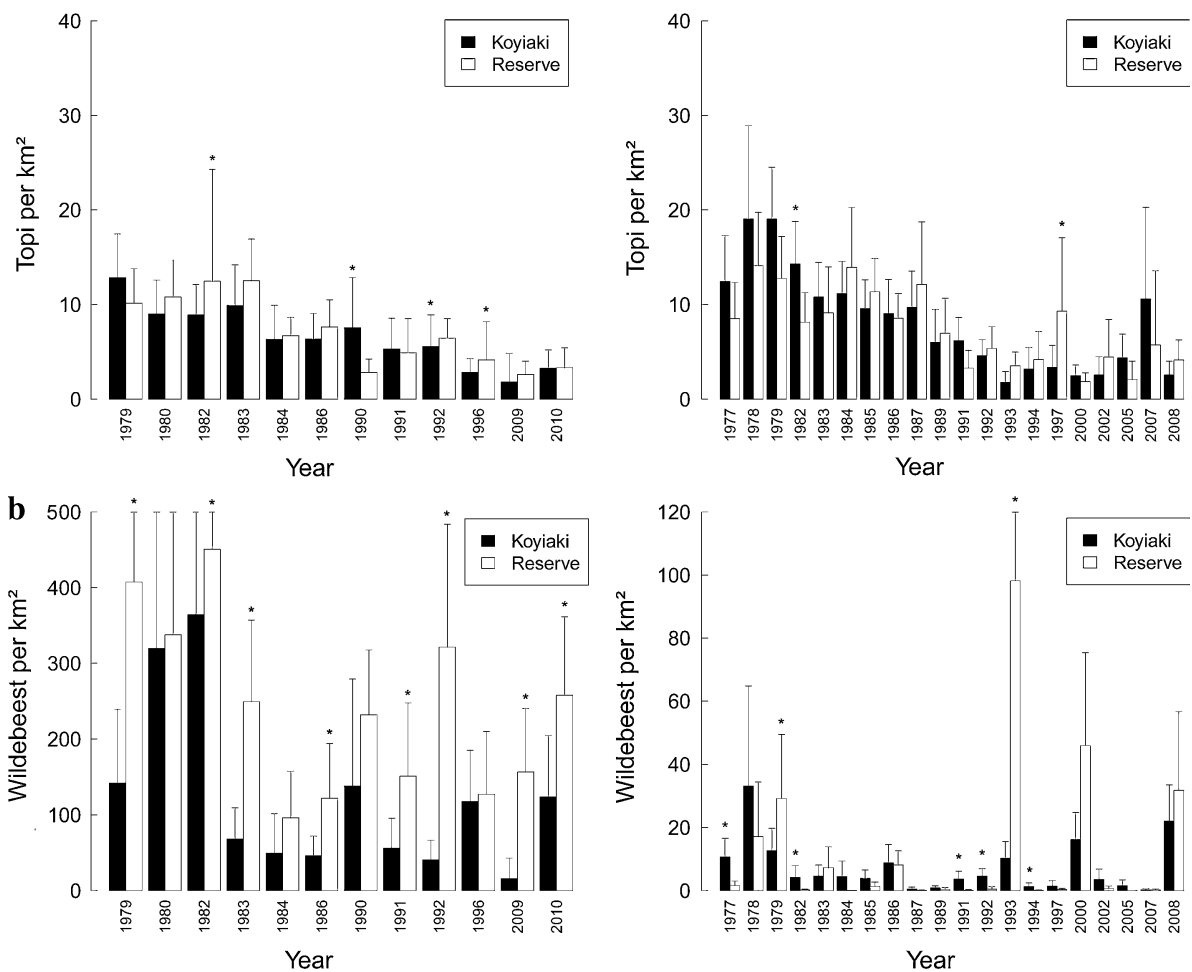

c

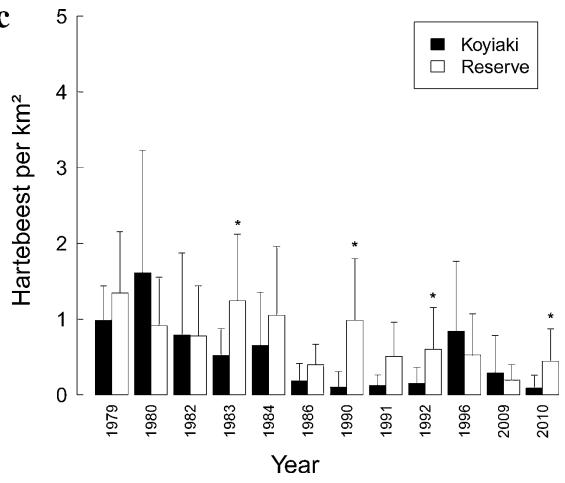

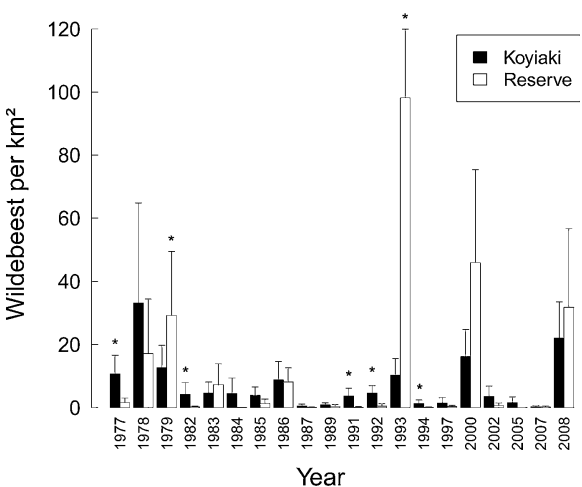

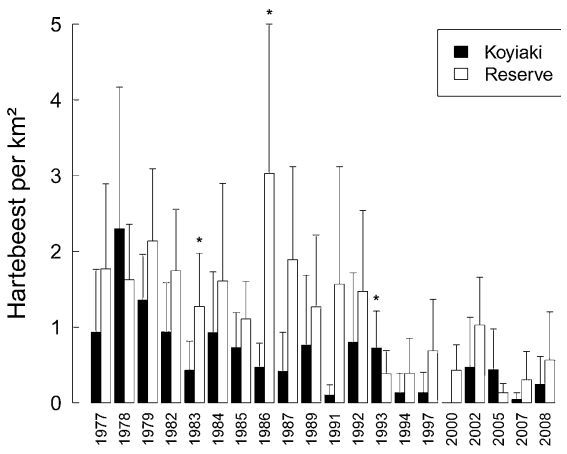

Year

Fig. 3 Comparative changes in densities (number $/ \mathrm{km}^{2}$ ) of medium pure grazers, a topi, b wildebeest, c hartebeest, $\mathbf{d}$ waterbuck, e cattle and f zebra between the Mara Reserve (light bars) and the adjoining Koyiaki pastoral ranch (dark bars) during the dry and wet seasons based on the DRSRS aerial surveys from 1977 to 2010. Vertical lines show the $95 \%$ pointwise confidence limits whereas stars indicate that the mean densities differed significantly between the reserve and Koyiaki

landscapes which are unrelated to livestock or human use, such as geomorphology, which can cause underlying differences in wildlife use, our results suggest that livestock and human use of the pastoral ranches are the two most important causes of the differences between the patterns we observed in the two landscapes. 

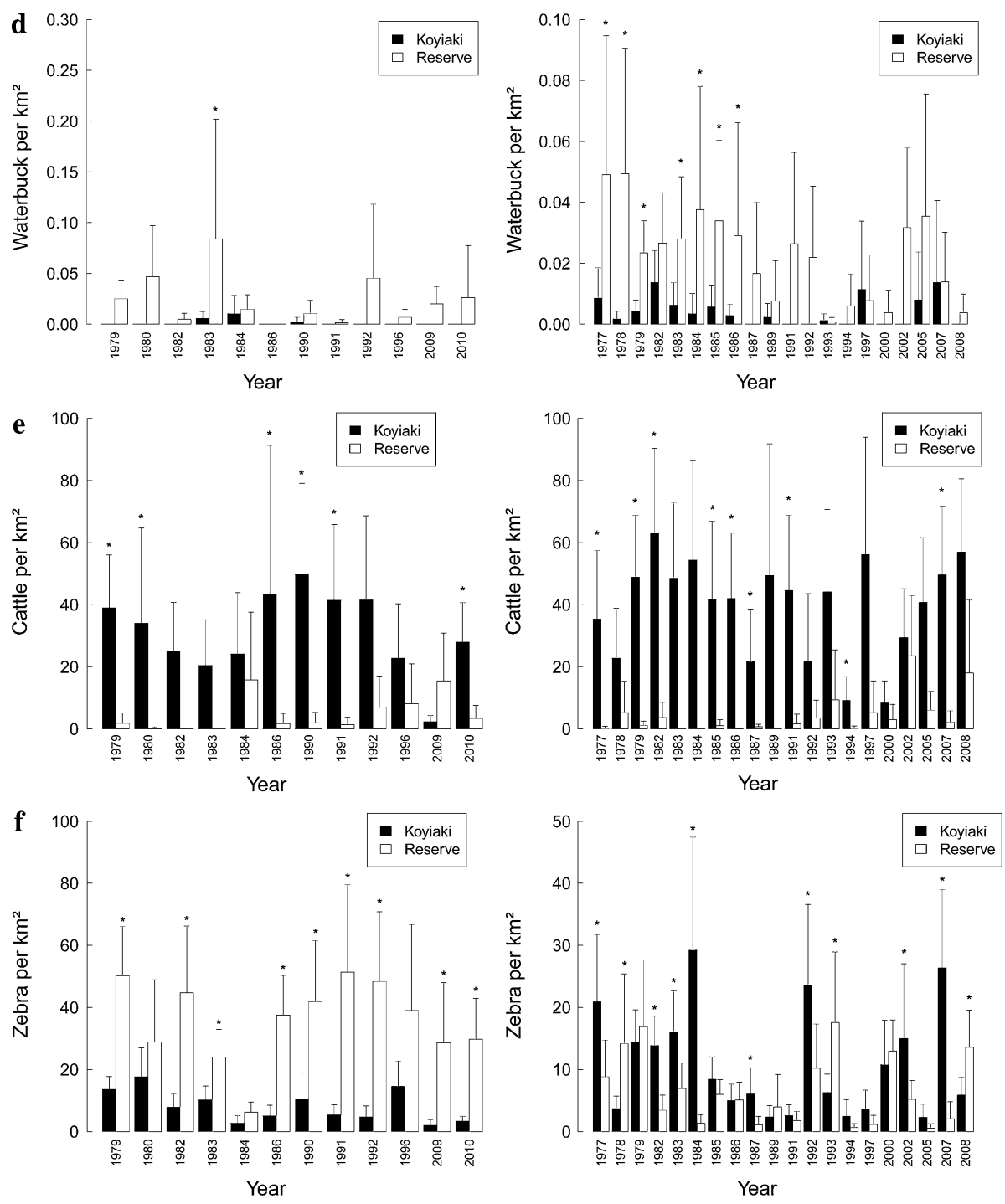

Fig. 3 continued

There were strong seasonal differences in wild herbivore densities between the reserve and the ranches during 1977-2010. Individual species responded differentially to pastoralism and protection. Three distinct patterns were apparent, all of which could be explained in terms of distinctions in body size and feeding guild and their consequences for nutritional quality and quantity of forage, predation risk and competition with livestock.

Small sized herbivores

Small species that are constrained by food quality and predation tend to prefer short grass areas (Fryxell 1991; Illius and Gordon 1992) and were thus more abundant in the ranches than the reserve regardless of season or feeding guild as revealed by the significant 

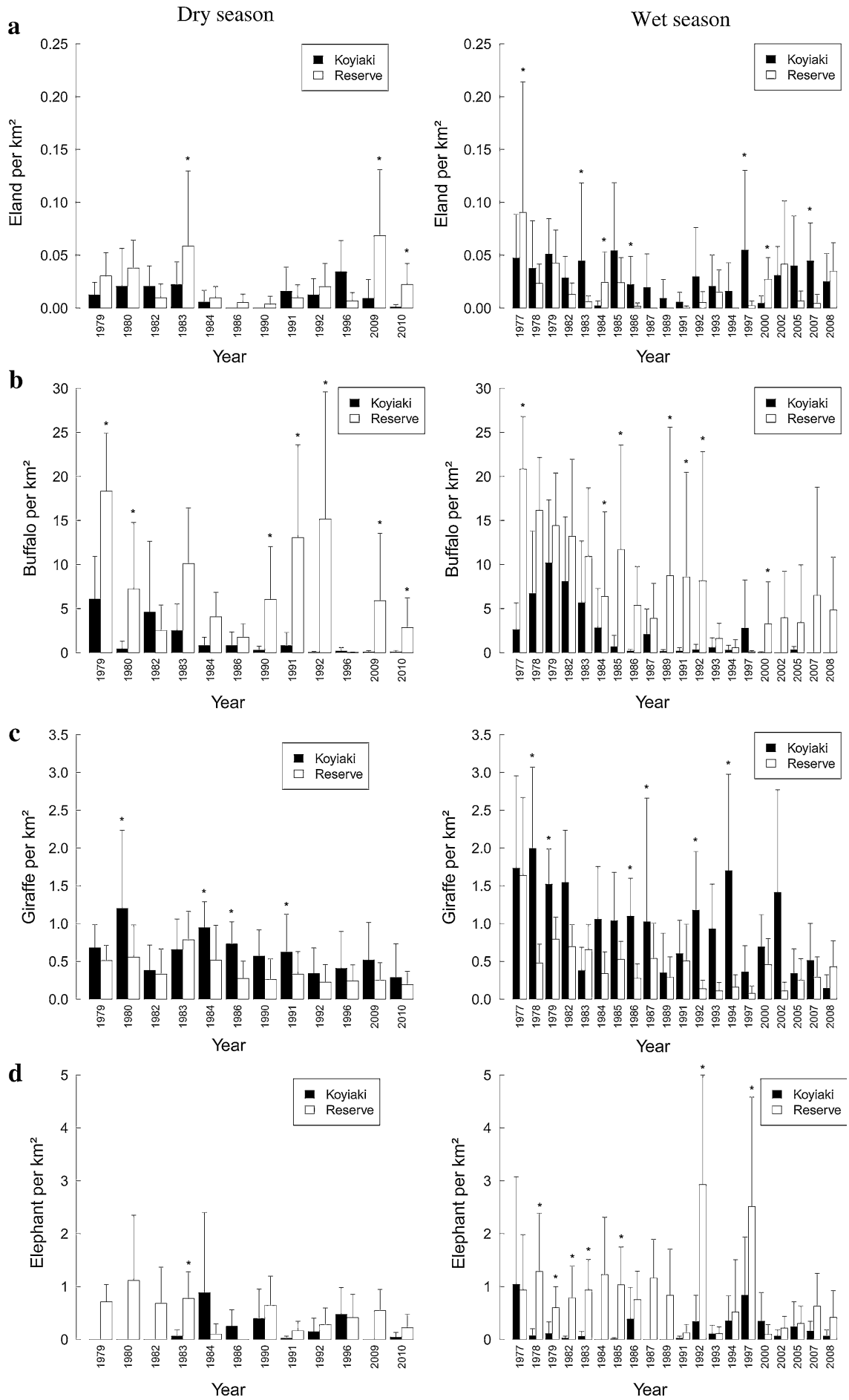
Fig. 4 Comparative changes in densities (number $/ \mathrm{km}^{2}$ ) of large pure grazers and mixed grazer/browsers, a eland, $\mathbf{b}$ buffalo, $\mathbf{c}$ giraffe and $\mathbf{d}$ elephant between the Mara Reserve (light bars) and the adjoining Koyiaki pastoral ranch (dark bars) during the dry and wet seasons based on the DRSRS aerial surveys from 1977 to 2010. Vertical lines show the $95 \%$ pointwise confidence limits whereas stars indicate that the mean densities differed significantly between the reserve and Koyiaki

differences between their densities in the reserve and the ranches during 1977-2010. Repeated livestock grazing in the same areas of the ranches probably increased the crude protein production of grasses (Anderson et al. 2010; Augustine et al. 2010), enabling the small grazers to derive sufficient energy by selecting high-quality forage from the lowbiomass areas (Fryxell et al. 2005). Reduced predation risk as a result of lower vegetation cover on the ranches (Ogutu et al. 2005) is yet another advantage of concentrating in the short grass plains, since tall grasses conceal ambush predators and significantly increase their efficiency at catching prey animals (Hopcraft et al. 2005). The distribution patterns we observed for small herbivores are therefore concordant with the initial expectation that small herbivores (except warthog) should concentrate in areas of relatively fewer predators (safer) and shorter grasses maintained by heavy livestock grazing in the ranches. This outcome also concurs with findings of studies encompassing a variety of spatial scales and species (Olff et al. 2002; Cromsigt and Olff 2006) besides reinforcing the notion that both predation and resource limitation act simultaneously in limiting herbivore populations (Sinclair et al. 2003).

\section{Medium sized herbivores}

The second pattern was expressed by species that moved between the ranches and the reserve seasonally, suggesting that they preferred either the reserve or the ranches depending on season. Specifically, the medium-sized topi, wildebeest and zebra moved seasonally between the reserve and the ranches, thus supporting our second prediction. As a result, medium herbivores had higher densities in the ranches in the wet season but higher densities in the reserve in the dry season. This pattern suggests that medium herbivores tend to utilize the ranches when water and short, nutritious grasses, created and maintained by heavy livestock grazing (Rannestad et al. 2006), are widely available, enabling them to enhance their total protein consumption (McNaughton 1976). In addition, the short grasses also enhance visibility of predators, thus potentially lowering predation risk in the ranches than the reserve (Hopcraft et al. 2005; Ogutu et al. 2005). In contrast, since heavy and sustained livestock grazing depletes both forage and surface water faster in the ranches than in the reserve (Reid et al. 2003), the medium-sized grazers are likely forced to disperse from the ranches to the reserve in the dry season to access more forage and water. Consequently, the medium-sized species were more abundant in the reserve during the dry season, implicating elevated competition with livestock on the ranches for food and water. These patterns accord with the finding of Odadi et al. (2011), who recently reported greater competitive effects of livestock on wildlife in the dry season when food is scarcest.

Interestingly, hartebeest and waterbuck, both medium-sized grazers that select long grasses (Murray and Brown 1993), did not conform to this pattern; instead, they showed a slight preference for the reserve where long grasses are more abundant year-round (Reid et al. 2003; Ogutu et al. 2005). Because zebra can process large quantities of low quality diet due to their non-ruminant digestive physiology than can, say, the ruminant wildebeest (Gwynne and Bell 1968; Ben-Shahar and Coe 1992) it could be argued that zebra should be more abundant in the reserve where tall grasses are more abundant in both seasons (Reid et al. 2003; Ogutu et al. 2005). The occurrence of zebra at high densities in the ranches may 
Table 2 Comparisons of mean herbivore densities between the Mara Reserve $\left(808 \mathrm{~km}^{2}\right)$ and Koyiaki pastoral ranch $\left(649 \mathrm{~km}^{2}\right)$ based on ground mapping censuses conducted in November 1999 and 2002

\begin{tabular}{|c|c|c|c|c|}
\hline \multirow[t]{2}{*}{ Species } & \multicolumn{2}{|c|}{ November 1999} & \multicolumn{2}{|c|}{ November 2002} \\
\hline & Ranches & Reserve & Ranches & Reserve \\
\hline Thomson's gazelle & 15.97 & 16.70 & 28.13 & 21.30 \\
\hline Sheep + goats & 31.28 & 2.02 & 61.96 & 9.19 \\
\hline Impala & 9.24 & 4.49 & 12.22 & 6.08 \\
\hline Warthog & 0.50 & 0.83 & 0.74 & 1.38 \\
\hline Grant's gazelle & 1.68 & 1.52 & 1.96 & 2.72 \\
\hline Topi & 2.68 & 4.38 & 3.79 & 4.21 \\
\hline Wildebeest & 12.75 & 79.21 & 25.58 & 108.35 \\
\hline Hartebeest & 0.14 & 0.38 & 0.16 & 0.42 \\
\hline Waterbuck & 0.25 & 0.34 & 0.35 & 0.27 \\
\hline Cattle & 16.84 & 4.08 & $\mathbf{3 4 . 3 0}$ & 15.98 \\
\hline Zebra & 7.90 & 11.95 & 15.80 & 21.01 \\
\hline Eland & 0.20 & 1.00 & 0.15 & 1.37 \\
\hline Buffalo & 0.50 & 1.27 & 0.08 & 1.31 \\
\hline Giraffe & 0.59 & 0.24 & 0.65 & 0.25 \\
\hline Elephant & 0.07 & 0.56 & 0.09 & 0.55 \\
\hline
\end{tabular}

Densities that differ significantly $(P<0.05)$ between the two landscapes in each year are highlighted in bold face font

Table 3 Tests for differences in age ratios (newborn/adult females, juveniles/adult females; for warthog and zebra adults of both sexes were used in place of adult females and subadults + adults/total) of each species between the Masai Mara Reserve and Koyiaki pastoral ranch based on pooled data for November 2003 and April 2004

\begin{tabular}{llllrrrr}
\hline Species & Age & Ranch & Reserve & \multicolumn{1}{c}{ LCL } & \multicolumn{1}{l}{ UCL } & \multicolumn{1}{c}{$\chi^{2}$} & \multicolumn{1}{c}{$P$} \\
\hline Warthog & Newborn & $\mathbf{0 . 4 1}$ & 0.17 & 0.04 & 0.42 & 7.58 & $<\mathbf{0 . 0 1}$ \\
Topi & & 0.02 & $\mathbf{0 . 0 6}$ & -0.06 & -0.01 & 10.44 & $<\mathbf{0 . 0 1}$ \\
Zebra & & 0.004 & $\mathbf{0 . 0 2}$ & -0.02 & -0.01 & 10.38 & $<\mathbf{0 . 0 1}$ \\
Impala & Juveniles & 0.12 & 0.12 & -0.03 & 0.02 & 0.10 & 0.74 \\
Warthog & & 0.13 & 0.30 & -0.32 & -0.01 & 3.35 & 0.06 \\
Topi & & $\mathbf{0 . 1 9}$ & 0.11 & 0.03 & 0.11 & 18.10 & $<\mathbf{0 . 0 1}$ \\
Zebra & & 0.07 & 0.08 & -0.03 & 0.003 & 2.23 & 0.13 \\
Giraffe & & 0.13 & 0.16 & -0.15 & 0.09 & 0.06 & 0.79 \\
Impala & \multirow{2}{*}{ Subadults + Adults } & 0.85 & 0.85 & -0.03 & 0.03 & 0.003 & 0.95 \\
Warthog & & 0.45 & 0.52 & -0.28 & 0.13 & 0.24 & 0.62 \\
Topi & & 0.78 & 0.82 & -0.08 & 0.01 & 2.98 & 0.08 \\
Zebra & & $\mathbf{0 . 9 2}$ & 0.59 & 0.01 & 0.05 & 7.28 & $<\mathbf{0 . 0 1}$ \\
Hartebeest & & 0.81 & 0.78 & -0.16 & 0.22 & 0.003 & 0.95 \\
Giraffe & & 0.79 & 0.74 & -0.10 & 0.20 & 0.24 & 0.62 \\
\hline
\end{tabular}

The total number aged in both landscapes and years was 2,410, 201, 2,284, 175, 7,957, and 183 for impala, warthog, topi, hartebeest, zebra and giraffe, respectively. LCL and UCL are the 95\% lower and upper binomial confidence limits for each age ratio, respectively

Bold values indicate the significance assessed at alpha $=0.05$ 
Table 4 Tests for differences in female proportions $(\mathrm{F} /(\mathrm{F}+\mathrm{M}))$ of each species between the Masai Mara Reserve and Koyiaki pastoral ranch based on pooled data for November 2003 and April 2004

\begin{tabular}{lllrrrr}
\hline Species & Ranch & Reserve & \multicolumn{1}{c}{ LCL } & \multicolumn{1}{c}{ UCL } & \multicolumn{1}{c}{$\chi^{2}$} & \multicolumn{1}{c}{$P$} \\
\hline Impala & 0.72 & 0.80 & 0.05 & 0.13 & 23.26 & $<\mathbf{0 . 0 1}$ \\
Topi & 0.46 & 0.56 & -0.15 & -0.03 & 10.40 & $<\mathbf{0 . 0 1}$ \\
Hartebeest & 0.54 & 0.62 & -0.34 & 0.18 & 0.17 & 0.68 \\
Giraffe & 0.57 & 0.59 & -0.22 & 0.17 & 0.00 & 0.93 \\
\hline
\end{tabular}

The total number sexed in both years and landscapes was 2,219, 1,381, 296, and 133 for impala, topi, hartebeest, and giraffe, respectively. LCL and UCL are the 95\% lower and upper confidence limits for each proportion

Bold values indicate the significance assessed at alpha $=0.05$

thus suggest attraction to the short, high-quality grasses there and/or lower predation risk, since zebra suffer heavy lion (Panthera leo) predation in the Mara-Serengeti ecosystem (Grange et al. 2004). The short grass plains in the ranches also may provide seasonal predator refugia for lekking topi (Bro-Jørgensen and Durant 2003).

\section{Large sized herbivores}

The third pattern involved species that prefer long grasses all year, or for part of the year and, thus are most likely to compete strongly with livestock. These species were more abundant in the reserve than in the ranches. Since species such as buffalo and elephant are exposed to less predation risk because of their very large body sizes (Sinclair et al. 2003), they do not have to avoid areas with high risk of predation (Hopcraft et al. 2011) and can therefore, relatively safely, use areas of high food abundance. Furthermore, by often occurring in large herds these herbivores, reduce predation risk even further. Also, their digestive physiology allows them to utilize the low-quality tall grasses predominantly found inside the reserve to maximize their specific metabolic requirements (Illius and Gordon 1992; Wilmshurst et al. 2000). The distribution patterns of the large herbivores thus conform to the expectation that large herbivores should select areas with taller grasses than small herbivores (Sinclair et al. 2003; Hopcraft et al. 2011). The patterns shown by the large-bodied eland did not conform fully to this expectation. Instead, eland moved seasonally between the reserve and the ranches. It is plausible that short, nutritious forbs which eland selects in the wet season (Watson and Owen-Smith 2000; Augustine et al. 2010) occurred at higher densities in the livestock-dominated areas in the ranches in the wet season. By contrast, giraffe are almost exclusively browsers favouring trees and shrubs and feeding almost entirely on forage at least $1 \mathrm{~m}$ off the ground (Owen-Smith and Cooper 1987). The ranches support 11-12\% woody cover and the reserve $4 \%$ as measured by Reid et al. (2003). This higher abundance of trees and shrubs on the ranches may be partially the result of rocky topography in parts of the ranches, but may also be because combined livestock and wildlife grazing removes more grass fuel on the ranches than in the reserve, thus discouraging extensive fires that suppress tree and shrub establishment (Scholes and Archer 1997). As a result, giraffe were more abundant in the ranches with more trees and shrubs in the wet season.

Comparisons of age ratios and female proportions between landscapes

We predicted that the lower number of predators, lower predation risk, and shorter grass (Ogutu et al. 2005), and better predator visibility (Kanga et al. 2011), will lead to a higher 
proportion of the pregnant females bearing and raising their young on the ranches than in the reserve. As expected, newborn warthog and juvenile topi were significantly more abundant in the ranches, suggesting a preference for shorter grass areas where predation risk is lower. Contrary to our expectation, however, the proportions of newborn topi and zebra were higher in the reserve, suggesting a push from pastoralists or a pull by something in the reserve, such as tall and dense grass cover for young to hide. The ratio of females to males varied significantly from parity for impala and topi, for which a female biased sex ratio is common (Sinclair et al. 2000). Our results suggest that female impala and topi were more abundant in the reserve, consistent with our speculation that competition with livestock and disturbance by humans and dogs in the ranches forces more females accompanied by their young into the reserve. Female giraffe and hartebeest were evenly distributed between the reserve and ranches, suggesting little influence of land use on the distribution of females relative to males.

Implications for pastoralism, wildlife management and conservation

Dispersal areas for wildlife in pastoral systems and their adjoining protected areas in African savannas represent wet season refuges for many wild herbivores that range seasonally beyond the protected area boundaries (Ogutu et al. 2008; Augustine et al. 2010).

Our study shows that these areas can, and indeed do, support a high diversity of wildlife, especially in the wet season when resources are widely available due to maintenance of grasslands by livestock in short, nutritious growth stage. However, several other studies have shown that increasing human population growth, settlement, cultivation and sedentarization of formerly semi-nomadic pastoralists in these areas are increasingly restricting seasonal wildlife movements (Serneels and Lambin 2001; Coughenour 2008; Ogutu et al. 2011) and potentially negating their otherwise positive effects on wildlife. These movements give both wildlife and livestock the flexibility and mobility necessary to optimally exploit heterogeneity in resources in space and time, including that caused by the directional impacts of a warming and drying climate (Ogutu et al. 2007). Our results reinforce and extend the conclusions of these studies by also revealing that, even though wildlife evidently move seasonally between the reserve and the ranches, their densities have declined strikingly in both the reserve and the ranches, most likely due to ongoing land use changes (Ogutu et al. 2009, 2011). Land use changes in the pastoral lands thus portend a precarious future for wild herbivores that depend on the pastoral areas. Furthermore, the land use changes exacerbate the adverse effects of recurrent climatic extremes on the availability of forage and water, forcing ever more pastoralists to graze their livestock illegally in protected areas (Butt et al. 2009; Ogutu et al. 2009). The land use changes also likely intensify competition between wildlife and livestock and thus adversely affect demographic processes such as reproduction and juvenile recruitment besides the seasonal dispersal movements of wild herbivores between protected areas and their adjoining pastoral lands. If the ongoing losses of key dispersal areas and calving grounds of wildlife in key ecosystems of East Africa, such as the Mara Region, continue unabated, they will accelerate wildlife population declines (Ogutu et al. 2011) and even cause local population extirpations (Newmark 1996).

We therefore suggest that effective management of pastoral lands as well as their adjoining protected areas in East Africa and possibly elsewhere is urgently necessary and should aim to prevent further losses of wildlife. Furthermore, management should aim to secure dispersal areas, including corridors for seasonal wildlife and livestock movements, and effectively couple traditional knowledge of seasonal herders, management and 
scientific knowledge (Reid et al. 2009) into an integrated approach incorporating both protected areas and their adjoining pastoral lands.

Acknowledgments We thank the Department of Resource Surveys and Remote Sensing of Kenya (DRSRS) and the International Livestock Research Institute (ILRI) for providing the data on wildlife surveys and two anonymous referees for constructive comments that helped improve an earlier draft of this paper. The University of Groningen supported NB through an Ubbo Emmius scholarship.

Open Access This article is distributed under the terms of the Creative Commons Attribution License which permits any use, distribution, and reproduction in any medium, provided the original author(s) and the source are credited.

\section{References}

Anderson TM, Ritchie ME, Mayemba E, Eby S, Grace JB, McNaughton SJ (2007) Forage nutritive quality in the Serengeti ecosystem: the roles of fire and herbivory. Am Nat 170:343-357

Anderson TM, Hopcraft JGC, Eby S, Ritchie M, Grace JB, Olff H (2010) Landscape-scale analyses suggest both nutrient and antipredator advantages to Serengeti herbivore hotspots. Ecology 91:1519-1529

Augustine DJ, Veblen KE, Goheen JR, Riginos C, Young TP (2010) Pathways for positive cattle-wildlife interactions in semi-arid rangelands. Smithsonian Contributions Zool 632:55-71

Ben-Shahar R, Coe MJ (1992) The relationships between soil factors grass nutrients and the foraging behaviour of wildebeest and zebra. Oecologia 90:422-428

Bro-Jørgensen J, Durant SM (2003) Mating strategies of topi bulls: getting in the centre of attention. Anim Behav 65:585-594

Broten MD, Said M (1995) Population trends of ungulates in and around Kenya's Maasai Mara Reserve. In: Sinclair ARE, Arcese P (eds) Serengeti II: dynamics management and conservation of an ecosystem. University of Chicago Press Chicago, Illinois, pp 169-193

Butt B, Shortridge A, WinklerPrins AMGA (2009) Pastoral herd management drought coping strategies and cattle mobility in southern Kenya. Ann Assoc Am Geogr 99:309-334

Caro TM (1999a) Demography and behaviour of African mammals subject to exploitation. Biol Cons 91:91-97

Caro TM (1999b) Densities of mammals in partially protected areas: the Katavi ecosystem of western Tanzania. J Appl Ecol 36:205-217

Coe MJ, Cumming DH, Phillipson J (1976) Biomass and production of large African herbivores in relation to rainfall and primary production. Oecologia 22:341-354

Coughenour MB (2008) Causes and consequences of herbivore movement in landscape ecosystems. In: Galvin KA, Reid RS, Hobbs RH, Behnke HT (eds) Fragmentation in semi-arid and arid landscapes: consequences for human and natural systems. Springer, Dordrecht, pp 45-91

Cromsigt J, Olff H (2006) Resource partitioning among savanna grazers mediated by Local heterogeneity: an experimental approach. Ecology 87:1532-1541

Demment MW, Van Soest PJ (1985) A nutritional explanation for body-size patterns of ruminant and nonruminant herbivores. Am Nat 125:641-672

Draper NR, Smith H (1998) Applied regression analysis. John Wiley and Sons, New York

Epp HJ, Agatsiva J (1980) Habitat types of the Mara-Narok area western Kenya. Kenya Rangelands Ecological Monitoring Unit (KREMU), Nairobi

Fritz H, Duncan P (1994) On the carrying-capacity of large ungulates of African savanna ecosystems. Proc R Soc Lond (Biol) 256:77-82

Fryxell JM (1991) Forage quality and aggregation by large herbivores. Am Nat 138:478-498

Fryxell JM, Wilmshurst JF, Sinclair ARE, Haydon DT, Holt RD, Abrams PA (2005) Landscape scale, heterogeneity, and the viability of Serengeti grazers. Ecol Lett 8:328-335

Galvin KA, Reid R, Behnke RH, Hobbs NT (eds) (2008) Fragmentation in semi-arid and arid landscapes: consequences for human and natural systems. Springer, Dordrecht

Georgiadis NJ, Olwero JGN, Ojwang G, Romanach SS (2007) Savanna herbivore dynamics in a livestockdominated landscape: I. Dependence on land use rainfall density and time. Biol Cons 137:461-472

Grange S, Duncan P, Gaillard J-M, Sinclair ARE, Gogan PJP, Packer C, Hofer H, East M (2004) What limits the Serengeti zebra population? Oecologia 140:523-532 
Gwynne MD, Bell RHV (1968) Selection of vegetation components by grazing ungulates in the Serengeti national park. Nature 220:390-393

Homewood K, Lambin EF, Coast E, Kariuki A, Kikula I, Kivelia J, Said M, Serneels S, Thompson M (2001) Long-term changes in Serengeti-Mara wildebeest and land cover: Pastoralism population or policies? Proc Natl Acad Sci 98:12544-12549

Homewood K, Kristjanson P, Trench PC (2009) Changing land use, livelihoods and wildlife conservation in Masailand. In: Homewood K, Kristjanson P, Trench PC (eds) Staying Masai? Livelihoods, conservation and development in East African rangelands. NewYork, Springer, pp 1-42

Hopcraft JCG, Sinclair ARE, Packer C (2005) Planning for success: Serengeti lions seek prey accessibility rather than abundance. J Anim Ecol 74:559-566

Hopcraft JGC, Olff H, Sinclair ARE (2010) Herbivores resources and risks: alternating regulation along primary environmental gradients in savannas. Trends Ecol Evol 25:119-128

Hopcraft JGC, Anderson TM, Pérez Vila S, Mayemba E, Olff H (2011) Body size and the division of niche space: food and predation differentially shape the distribution of Serengeti grazers. J Anim Ecol. doi: 10.1111/j.1365-2656.2011.01885.x

Illius AW, Gordon IJ (1992) Modelling the nutritional ecology of ungulate herbivores: evolution of body size and competitive interactions. Oecologia 89:428-434

Kanga EM, Ogutu JO, Olff H, Piepho H-P (2011) Hippopotamus and livestock grazing: influences on riparian vegetation and facilitation of other herbivores in the Mara Region of Kenya. Landscape Ecol Eng. doi:10.1007/s11355-011-0175-y

Lamprey RH, Reid RS (2004) Expansion of human settlement in Kenya's Maasai Mara: what future for pastoralism and wildlife? J Biogeog 31:997-1032

Lesnoff M, Lancelot R (2010) aod: analysis of overdispersed data R package version 12 URL http://cranr-projectorg/package=aod

Maddock L (1979) The "migration" and grazing succession In: Sinclair, ARE, Norton-Griffiths M (eds) Serengeti: dynamics of an ecosystem University of Chigaco Press, Chicago, Illinois, pp 105-129

McNaughton SJ (1976) Serengeti migratory wildebeest facilitation of energy flow by grazing. Science 191:92-94

Msoffe FU, Kifugo SK, Said MY, Neselle MO, van Gardingen P, Reid RS, Ogutu JO, Herero M, deLeeuw J (2011) Drivers and impacts of land-use change in the Maasai Steppe of northern Tanzania: an ecological-social-political analysis. J Land Use Sci. doi:I:10.1080/1747423X.2010.511682

Muchiru, AN, Western, DJ. Reid, RS (2008) The role of abandoned pastoral settlements in the dynamics of African large herbivore communities. Journal of Arid Environments. 72:940-952

Murray MG, Brown D (1993) Niche separation of grazing ungulates in the Serengeti—an experimental test. J Anim Ecol 62:380-389

Mworia JK, Kinyamario JI, Githaiga JM (2008) Influence of cultivation, settlements and water sources on wildlife distribution and habitat selection in south-east Kajiado, Kenya. Environ Conserv 35:117-124

Newmark WD (1996) Insularization of Tanzanian parks and the local extinction of large mammals. Conserv Biol 10:1549-1556

Norton-Griffiths M (1978) Counting animals handbook No. 1, 2nd edn. African Wildlife Leadership Foundation, Nairobi

Norton-Griffiths M, Said M, Serneels S, Kaelo, DS, Coughenour M, Lampry RH, Thompson DM, Reid, RS (2008) Land use economics in the Mara Area of the Serengeti Ecosystem. Serengeti III: Human impacts on ecosystem dynamics (eds A.R.E. Sinclair, C. Packer, S.A.R. Mduma \& J.M. Fryxell), pp 379-416. University of Chicago Press, Chicago

Odadi WO, Karachi MK, Abdulrazak SA, Young TP (2011) African wild ungulates compete with or facilitate cattle depending on season. Science 333:1753-1755

Ogutu JO, Bhola N, Reid R (2005) The effects of pastoralism and protection on the density and distribution of carnivores and their prey in the Mara ecosystem of Kenya. J Zool 265:281-293

Ogutu JO, Bhola N, Piepho H-P, Reid R (2006) Efficiency of strip-and line-transect surveys of African savanna mammals. J Zool 269:149-160

Ogutu JO, Piepho H-P, Dublin HT, Bhola N, Reid RS (2007) El Nino-Southern Oscillation rainfall temperature and Normalized Difference Vegetation Index fluctuations in the Mara-Serengeti ecosystem. Afr J Ecol 46:132-143

Ogutu JO, Piepho H-P, Dublin HT, Bhola N, Reid RS (2008) Rainfall influences on ungulate population abundance in the Mara-Serengeti ecosystem. J Anim Ecol 77:814-829

Ogutu JO, Piepho H-P, Dublin HT, Bhola N, Reid RS (2009) Dynamics of Mara-Serengeti ungulates in relation to land use changes. J Zool 278:1-14

Ogutu JO, Piepho H-P, Reid RS, Rainy ME, Kruska RL, Worden JS, Nyabenge M, Hobbs NT (2010) Large herbivore responses to water and settlements in savannas. Ecol Monogr 80:241-266 
Ogutu JO, Owen-Smith N, Piepho H-P, Said MY (2011) Continuing wildlife population declines and range contraction in the Mara region of Kenya during 1977-2009. J Zool 284:99-109

Olff H, Ritchie ME, Prins HHT (2002) Global environmental controls of diversity in large herbivores. Nature 415:901-904

Ottichilo WK (1999) Comparison of sample and total counts of elephant and buffalo in Masai Mara Kenya. Afr J Ecol 37:435-438

Ottichilo WK, Khaemba WM (2001) Validation of observer and aircraft calibration for aerial surveys of animals. Afr J Ecol 39:45-50

Ottichilo WK, De Leeuw J, Skidmore AK, Prins HHT, Said MY (2000) Population trends of large nonmigratory wild herbivores and livestock in the Masai Mara ecosystem Kenya between 1977 and 1997. Afr J Ecol 38:202-216

Ottichilo WK, de Leeuw J, Prins HHT (2001) Population trends of resident wildebeest [Connochaetes taurinus hecki (Neumann)] and factors influencing them in the Masai Mara ecosystem Kenya. Biol Cons 97:271-282

Owen-Smith N (1988) Megaherbivores: The influence of very large body size on ecology Cambridge University Press, Cambridge

Owen-Smith N, Cooper SM (1987) Palatability of woody plants to browsing ruminants in a South African savanna. Ecology 68:319-331

Pennycuick L, Norton-Griffiths M (1976) Fluctuations in the rainfall of the Serengeti ecosystem, Tanzania. J Biogeogr 3:239-245

R Development Core Team (2010) R: a language and environment for statistical computing. Viennna, Austria

Rannestad OT, Danielsen T, Moe SR, Stokke S (2006) Adjacent pastoral areas support higher densities of wild ungulates during the wet season than the Lake Mburo National Park in Uganda. J Trop Ecol 22:675-683

Reid RS, Rainy M, Ogutu J et al (2003) People wildlife and livestock in the Mara ecosystem: Report Mara Count 2002. International Livestock Research Institute, Nairobi

Reid RS, Gichohi H, Said M et al (2008) Fragmentation of a peri-urban Savanna Athi-Kaputiei Plains Kenya. In: Galvin KA, Reid RS, Behnke RH, Hobbs HT (eds) Fragmentation in semi-arid and arid landscapes: consequences for human and natural systems. Springer, Dordrecht, pp 195-224

Reid RS, Nkedianye D, Said MY et al. (2009) Evolution of models to support community and policy action with science: balancing pastoral livelihoods and wildlife conservation in savannas of East Africa. Proc Nat Acad Sci. xx:1-6

Scholes RJ, Archer SR (1997) Tree-grass interactions in savannas. Annu Rev Ecol Syst 28:517-544

Sensenig RL, Demment MW, Laca EA (2010) Allometric scaling predicts preferences for burned patches in a guild of East African grazers. Ecology 91:2898-2907

Serneels S, Lambin EF (2001) Impact of land-use changes on the wildebeest migration in the northern part of the Serengeti-Mara ecosystem. J Biogeogr 28:391-407

Serneels S, Said MY, Lambin EF (2001) Land cover changes around a major east African wildlife reserve: the Mara Ecosystem (Kenya). Int J Remote Sens 22:3397-3420

Sinclair ARE (1995) Population limitation of resident herbivores. In: Sinclair ARE, Arcese P (eds) Serengeti II: dynamics, management and conservation of an ecosystem. University of Chicago Press, Chicago, pp 194-219

Sinclair ARE (1998) Natural regulation of ecosystems in protected areas as ecological baselines. Wildl Soc Bull 26:399-409

Sinclair ARE, Mduma SAR, Arcese P (2000) What determines phenology and synchrony of ungulate breeding in Serengeti? Ecology 81:2100-2111

Sinclair ARE, Mduma SAR, Arcese P (2002) Protected areas as biodiversity benchmarks for human impact: agriculture and the Serengeti avifauna. Proc R Soc Lond B 269:2401-2405

Sinclair ARE, Mduma S, Brashares JS (2003) Patterns of predation in a diverse predator-prey system. Nature 425:288-290

Stelfox JG, Peden DG, Epp H, Hudson RJ, Mbugua SW, Agatsiva JL, Amuyunzu CL (1986) Herbivore dynamics in Southern Narok Kenya. J Wildl Manage 50:339-347

Stoner C, Caro T, Mduma S, Mlingwa C, Sabuni G, Borner M, Schelten C (2007) Changes in large herbivore populations across large areas of Tanzania. Afr J Ecol 45:202-215

Thirgood S, Mosser A, Sebastian T, Hopcraft G, Mwangomo E, Mlengeya T, Kilewo M, Fryxell J, Sinclair ARE, Borner M (2004) Can parks protect migratory ungulates? The case of the Serengeti wildebeest. Anim Conserv 7:113-120

Thompson M, Homewood K (2002) Entrepreneurs, elites and exclusion in Maasailand: trends in wildlife conservation and pastoralist development. Hum Ecol 30:107-138 
Wallgren M, Skarpe C, Bergström R, Danell K, Bergström A, Jakobsson T, Karlsson K, Strand T (2009) Influence of land use on the abundance of wildlife and livestock in the Kalahari Botswana. J Arid Environ 73:314-321

Watson LH, Owen-Smith N (2000) Diet composition and habitat selection of eland in semi-arid shrubland. Afr J Ecol 38:130-137

Western D (1975) Water availability and its influence on the structure and dynamics of a savannah large mammal community. Afr J Ecol 13:265-228

Western D, Groom R, Worden J (2009) The impact of subdivision and sedentarization of pastoral lands on wildlife in an African savanna ecosystem. Biol Cons 142:2538-2546

Wilmshurst JF, Fryxell JM, Bergman CM (2000) The allometry of patch selection in ruminants. Proc R Soc Lond B 267:345-349

Wittemyer G, Elsen P, Bean WT, Burton ACO, Brashares JS (2008) Accelerated human population growth at protected area edges. Science 321:123-126 